\title{
Is It Possible to Distinguish Global and Regional Climate Change from Urban Land Cover Induced Signals? A Mid-Latitude City Example
}

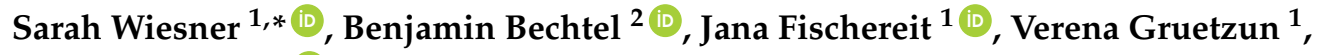 \\ Peter Hoffmann ${ }^{3}$ (D), Bernd Leitl ${ }^{1}$, Diana Rechid ${ }^{4}$, K. Heinke Schlünzen ${ }^{1}$ and Simon Thomsen ${ }^{5}$ \\ 1 Meteorological Institute, CEN, Universität Hamburg, 20146 Hamburg, Germany; \\ jana.fischereit@uni-hamburg.de (J.F.); verena.gruetzun@uni-hamburg.de (V.G.); \\ bernd.leitl@uni-hamburg.de (B.L.); heinke.schluenzen@uni-hamburg.de (K.H.S.) \\ 2 Institute of Geography, CEN, Universität Hamburg, 20146 Hamburg, Germany; \\ benjamin.bechtel@uni-hamburg.de \\ 3 Department of Mathematics, CEN, Universität Hamburg, 20146 Hamburg, Germany; \\ peter.hoffmann@uni-hamburg.de \\ 4 Climate Service Center Germany (GERICS), Helmholtz-Zentrum Geesthacht, 20095 Hamburg, Germany; \\ diana.rechid@hzg.de \\ 5 Department of Biology, CEN, Universität Hamburg, 20146 Hamburg, Germany; \\ simon.thomsen@uni-hamburg.de \\ * Correspondence: sarah.wiesner@uni-hamburg.de; Tel.: +49-404-2838-5158
}

Received: 21 December 2017; Accepted: 26 January 2018; Published: 31 January 2018

\begin{abstract}
The local climate in cities differs from the one in rural areas, most prominently characterized by increased surface and air temperatures, known as the "(surface) urban heat island". As climate has changed and continues to change in all areas of the world, the question arises whether the effects that are noticeable in urban areas are "homemade", or whether some of them originate from global and regional scale climate changes. Identifying the locally induced changes of urban meteorological parameters is especially relevant for the development of adaptation and mitigation measures. This study aims to distinguish global and regional climate change signals from those induced by urban land cover. Therefore, it provides a compilation of observed and projected climate changes, as well as urban influences on important meteorological parameters. It is concluded that evidence for climate change signals is found predominantly in air temperature. The effect of urban land cover on local climate can be detected for several meteorological parameters, which are air and surface temperature, humidity, and wind. The meteorology of urban areas is a mixture of signals in which the influencing parameters cannot be isolated, but can be assessed qualitatively. Blending interactions between local effects and regional changes are likely to occur.
\end{abstract}

Keywords: urban climate; climate change; urban heat island; regional climate; local scale; mid-latitude city; meteorological parameters

\section{Introduction}

As urban climate is one of the core topics within the atmospheric sciences, it needs to be set in relation to the prevailing main issue: global climate change. Global effects are well researched, and regional changes become more and more assessed, mainly by using numerical models [1]. Apart from that, observational data are used to assess past changes, and measurements as well as high-resolution models of the mesoscale and microscale are considered to assess the effects of urban land cover on local climate. The term "urban land cover" in the following comprises land-use and 
buildings' shape, the surface coverage ratio, surface materials, as well as natural matters (e.g., trees, water bodies) within the city.

To define the phrases "global/regional" and "local" scale as used in this article, Figure 1 depicts the different scales and relations. While global and regional scale phenomena have a wider horizontal extension than urban scale phenomena, local scale phenomena are of a very small horizontal extension. Humans are actively impacting phenomena on (nearly) all temporal and spatial scales, either directly as in urban climate or indirectly as in global climate change by emission of greenhouse gasses. For detection and understanding of changes on various scales, observations and modelling techniques are needed, which both have their advantages and drawbacks.

While measurement data are always comprised of both local and global phenomena, model simulations most often do only consider either the one or the other cause (global trends or locally induced changes) [2]. Thus, especially high-resolution models are often set-up independent of regional climate changes to solely study the effects of urban land cover. Yet, to be able to assign a concise cause to the observed "truth" (i.e., the changed meteorological parameter), it is crucial to establish effective adaptation and mitigation strategies.

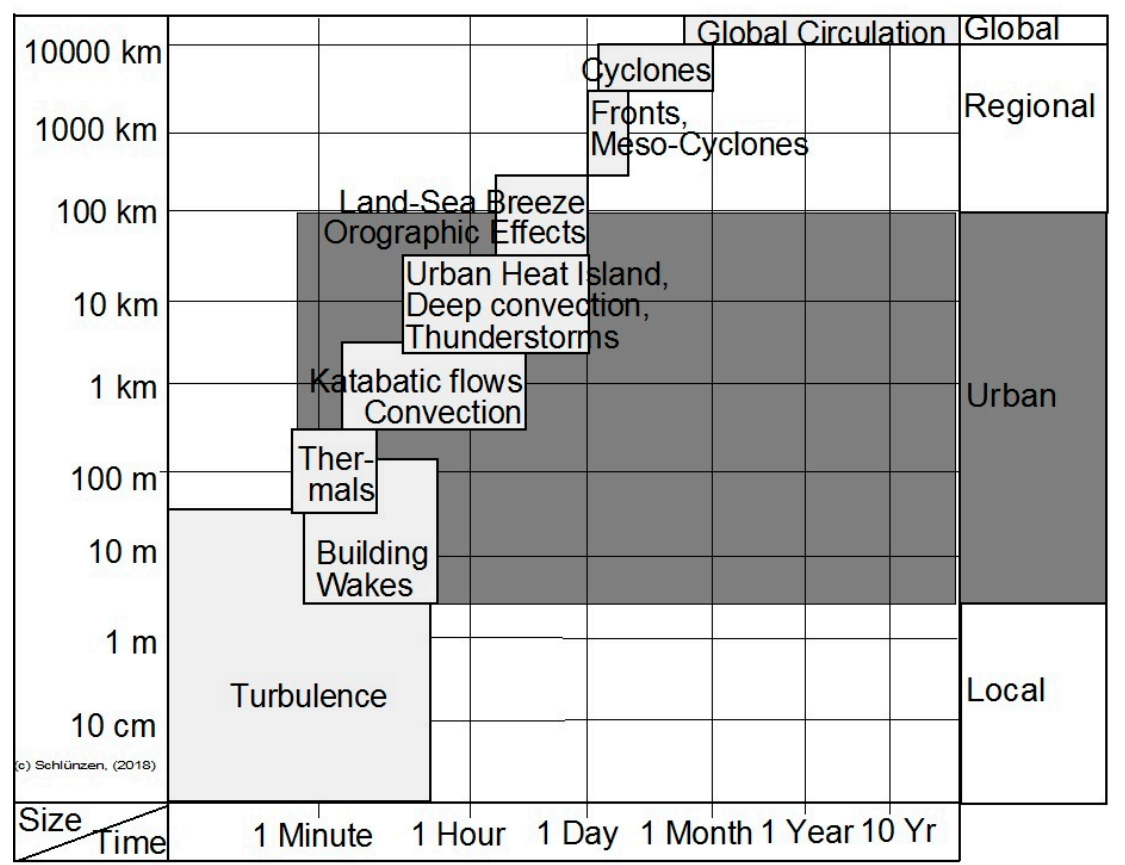

Figure 1. Scale diagram of atmospheric phenomena with their characteristic time and horizontal extension (based on [3]) and highlighting of the urban scale.

For identifying urban scale processes, mesoscale and microscale models are used; these need to parameterize some small scale processes that are below the grid size. Processes larger than the model domain size need to be prescribed (boundary values). Processes of scales in between can be directly simulated by these models.

The aims of this article are to:

(1) Assess which effects are locally enforced and due to direct human influence, and which changes are induced by regional and global change.

(2) Provide insights on local effects of urban areas and their magnitude compared to regional climate change signals.

(3) Answer these three questions: Can local meteorological phenomena be assigned to either general climate change effects or urban land cover? Are there impacts of interactions of both? How can these factors be determined and quantified? 
These questions are addressed by fusing the current knowledge on climate change and urban climate with detailed process studies, performed for the city of Hamburg, Germany. For this city, several research projects investigated the urban system with all its components leading to a conceptual model with a focus on urban health and wellbeing [4]. However, to quantitatively describe reactions of the urban system to external and internal changes in meteorological parameters and land cover, the signals from both origins need to be distinguished. This is attempted by using observed in situ and remotely sensed data as well as model results for detailed analyses of time series and data interpretation via geographic information systems (GIS), as well as atmospheric model simulations, including downscaling. As air temperature is a well-studied meteorological parameter for which research results are rated as most reliable, it is discussed in-depth (Section 2), followed by other meteorological variables (Section 3). Section 4 summarizes the main results.

It should be noted that the individual climate parameters do not only differ in value, but in some cases they also originate from different time periods, spatial regions, and, if applicable, selected simulations. The reason for this is the use of different publications in these analyses; the different impacts are mentioned, whenever they are known.

\section{Air Temperature}

\subsection{Global and Regional Observations and Projections}

Observational records of the global mean temperature show long-term warming trends since the end of the 19th century, with an increased warming since the 1970s. Three independent analyses of global mean temperature using near-surface observation Hadley Centre/Climate Research Unit Temperature dataset version 4 (HadCRUT4) [5], National Oceanic and Atmospheric (NOAA) Global Temp [6], and GISS Surface Temperature Analysis (GISTEMP) by the National Aeronautics and Space Administration (NASA) Goddard Institute for Space Studies (GISS) [7] show similar trends [8]. For the time period from January 1979 to July 2016, the linear trend is $0.16 \mathrm{~K} /$ decade to $0.18 \mathrm{~K} /$ decade. The long-term warming trend from pre-industrial times (mid-1700s) to 1981-2010 is taken as $0.7 \mathrm{~K}$ by Simmons et al. [8]; they concluded that global mean surface temperatures reached $1 \mathrm{~K}$ above the mid-1700s level in 2016. This magnitude of warming corresponds to half of the $2 \mathrm{~K}$ warming which is set as the upper limit in the Paris Agreement, but which does not precisely define the pre-industrial baseline [9]. The global climate projections of the Coupled Model Intercomparison Project Phase 5 (CMIP5), as summarized in the Intergovernmental Panel on Climate Change (IPCC) 5th Assessment Report [1] for several Representative Concentration Pathways (RCP) scenarios, project further increases in global average temperature over the 21st century (2081-2100 relative to 1986-2005) by 0.3 to $1.7 \mathrm{~K}$ for the lowest emissions scenario (RCP2.6) and 2.6-4.8 K for the highest emissions scenario (RCP8.5). The projections for a given $\mathrm{RCP}$ vary due to internal climate variability and modelling uncertainties. All projections show larger warming over land areas than over oceans.

A basis for the observed past trends of European average temperature is the Ensembles OBServational dataset (E-OBS) gridded data set [10]. Based on this data, van der Schrier et al. [11] estimated a trend of near surface temperature for the period 1950-2010 of $0.18 \mathrm{~K} /$ decade, for the 1980-2010 period of $0.41 \mathrm{~K} /$ decade. Concerning the projections, in the frame of the coordinated downscaling experiments for Europe (EURO-CORDEX), a sample of the global climate simulations of CMIP5 was downscaled with regional climate models for Europe on $0.11^{\circ}$ horizontal resolution [12]; according to the multi-model ensemble mean, temperature increases across European land areas are projected in the spatial range of $1-4.5 \mathrm{~K}$ for the RCP4.5 scenario and of $2.5-5.5 \mathrm{~K}$ for RCP8.5 over the 21st century (2071-2100 relative to 1971-2000).

For Germany, Kaspar and Mächtel [13] report a mean temperature trend of $1.3 \mathrm{~K}$ for the time period of 1881-2014. The frequency of the occurrence of extreme high temperatures increases, and longer heat waves are detected [14]. Based on the EURO-CORDEX multi-model ensemble, winter temperatures are projected to increase by $1.2-3.2 \mathrm{~K}$ for RCP4.5 and 3.2-4.6 K for RCP8.5 for the end 
of the century (2071-2100 relative to 1971-2000); summer temperatures are projected to increase by 1.3-2.6 K for RCP4.5 and 2.7-4.8 K for RCP8.5 (2071-2100 relative to 1971-2000) [15]. Furthermore, extreme high temperatures and heat waves are projected to occur with increasing frequency, which is much more pronounced in RCP8.5 [14,15].

At the measurement station Hamburg-Fuhlsbüttel, the observed annual mean temperature in the time period 1971-2000 was $9.0^{\circ} \mathrm{C}$ calculated on the basis of data from the German Meteorological Service (DWD) Climate Data Center [16]. At this station, a temperature trend of $1.65 \mathrm{~K}(\sim 0.21 \mathrm{~K} /$ decade) was observed in the time period 1936-2015. Looking at the shorter time period from 1970 to 2015, the trend was $1.54 \mathrm{~K}(\sim 0.34 \mathrm{~K} /$ decade). Climate change projections are available for the larger area of the Metropolitan region of Hamburg. Here, the annual mean temperature is projected to increase in the range of 1-5 K according to [17]. Based on the EURO-CORDEX multi-model ensemble-the same ensemble as used in [15] for Germany-winter temperatures are projected to increase in the Metropolitan Region of Hamburg by 1.1-3.1 K for RCP4.5 and 2.9-4.4 K for RCP8.5 for the end of the century; summer temperatures are projected to increase by $1.2-2.5 \mathrm{~K}$ for RCP4.5 and $2.1-4.3 \mathrm{~K}$ for RCP8.5 (2071-2100 relative to 1971-2000) (own analysis).

Van der Schrier et al. [11] compared E-OBS based European mean temperature to the trend of global land area based on Climatic Research Unit land station TEMperature dataset version $4 \mathrm{v}$ (CRUTEM4v) (mean temperature over global land areas of the HadCRUT4 data set). For the time period 1980-2010, Europe warmed approximately 1.6 times faster than the global land area [11]. The differences between global and regional changes are due to changing large scale weather patterns interacting at regional and local scales with smaller scale processes such as mesoscale atmospheric circulation patterns and with regional and urban factors such as topography, land cover, and land-sea distribution. This leads to spatially varying patterns of climate changes.

\subsection{Urban Heat Island}

The urban heat island (UHI), the urban-rural temperature difference in the surface near atmosphere as described by Oke [18], is a result of the changed urban morphology, fabric, and cover. This provides increased heat storage during the day, increased heat release at night, lower evaporation, and modified radiation balance, and thus changes the surface energy budget. In addition, anthropogenic heat emissions are a time dependent heat source within the urban areas. The UHI has a daily and an annual cycle, with enhanced temperatures especially in the late evening hours and at night. The intensity of the UHI depends on the prevailing wind speed and the cloudiness. In radiation intensive, weak wind steady weather situations, the UHI is most pronounced [19]. Thus, UHIs are particularly distinct in calm summer nights with a clear sky (e.g., [20-22]).

To calculate the actual value of a local UHI intensity, in-situ measurements in the regarded city area are often used and set in relation to data of rural areas or the vicinity (i.e., areas outside the city, indicated by lined border in Figure 3a). This can be done using single values for a certain point in time ("spatial urban heat island") or using values collected over a certain time, like daily/monthly/annual means or maxima/minima ("temporal urban heat island") [23]. For Hamburg, Germany, the analyses of measurement data showed an UHI of up to $1.2 \mathrm{~K}$ in the average temperature (regression with floristic proxy data and measurements [24]). Depending on the local urban land cover, the average temperature differences compared to the surrounding area are differentiated by the urban structure with $0.25 \mathrm{~K}$ for suburban districts [25], 0.5-0.7 $\mathrm{K}$ for suburbs and outskirt districts [20], $0.9 \mathrm{~K}$ at an industrial suburban area [26], and up to $1.2 \mathrm{~K}$ for the inner city $[20,25,27]$.

The differences are smaller during the day [20,25] and usually show a seasonal pattern and diurnal differences. Largest UHI values are found at night, again with a large spatial spread of the differences. These range from $0.7 \mathrm{~K}$ (suburb) to $1.7 \mathrm{~K}$ (central district) in winter and from $0.9 \mathrm{~K}$ (suburb) to $2.7 \mathrm{~K}$ (central district) in summer compared to a rural measuring station [19], (p. 54). In rare cases, much higher values are found, reaching $6 \mathrm{~K}$ [27] for the city center, $6.9 \mathrm{~K}$ as the 90th percentile for the central urban area [25], and $10.5 \mathrm{~K}$ as a single value [28] for the inner city. Such high temperature differences 
to the surrounding area are seldom and cannot be clearly assigned solely to anthropogenic influence. However, temperature peaks are unevenly distributed in the urban area, being connected to the variety of surfaces. Urban climate is also dependent on water bodies: inner-city water bodies may cool the city by advecting cool air during the day and keep temperatures relatively high at night, as the water surfaces attenuate the diurnal cycle. This results in heat island-like effects at night by advection of warm air from adjacent water bodies [20].

\subsection{Development of the UHI in the Past}

Regarding the development of the UHI within the past decades, threshold days give a good picture of differences in the annual temperature distribution between urban and rural areas. These are, for example, the so-called summer days or the hot days (daily maximum temperature at least $25^{\circ} \mathrm{C}$, or $30^{\circ} \mathrm{C}$, respectively) or the tropical nights (minimum temperature not below $20^{\circ} \mathrm{C}$ ). Trusilova and Riecke [29] calculated the mean annual number of summer days, hot days, and tropical nights for Hamburg and the vicinity (here defined as the areal mean of the adjacent state of Schleswig-Holstein) from measurement for the evaluation period 1989-2008 (Table 1).

Table 1. Mean annual number of threshold days as measured for Hamburg (areal mean) and vicinity (areal mean of rural areas in Schleswig-Holstein) for the period 1989-2008 (data retrieved from [29]).

\begin{tabular}{ccc}
\hline Mean Number of Days/Year & Hamburg & Vicinity \\
\hline summer days & 31 & 22 \\
hot days & 6 & 3 \\
tropical nights & 1 & 0 \\
\hline
\end{tabular}

Within the regarded 20 years, the number of all threshold days is higher in Hamburg with nine summer days, three hot days, and one tropical night in addition per year, which appears to be the locally induced effect. Also, for other cities such as London, simulations of the temporal trend of the UHI effect showed that threshold values were exceeded more often in recent years [23].

Another way of investigating the urban impact on air temperatures is statistically analyzing the observed temperature trends from measurements in urban and rural data, where urbanization indicators such as population, urban land cover, and energy consumptions are used to distinguish between urban and rural areas [30-35]. Due to the lack of rural measurements in regions with rapid urbanization, re-analysis data are used as rural background data [30,33]. Especially in regions with rapid urbanization, such as parts of the US [30] and China [33,35], temperature trends in urban areas were larger compared to temperature trends in rural areas. For Europe, there are no consistent results. For example, Chrysanthou et al. [31] found statistically significant increases of European annual, spring, and summer temperature trends due to urbanization. In contrast, Jones et al. [32] showed that both for London and Vienna urban stations have similar temperature trends as rural stations, which they attributed to the comparably small urbanization over the course of the 20th century. Figure 2 presents such an analysis for the $2 \mathrm{~m}$ annual mean temperature at two stations in Hamburg (airport Hamburg-Fuhlsbüttel and downtown). The regional temperature signals were obtained by averaging Climatic Research Unit Time-Series version 3.25 (CRUTS3.25) data [36] for the region of Hamburg using the boundaries as applied in Schoetter et al. [37]. This regional mean (blue in Figure 2a) shows a larger trend than the global mean (black in Figure 2a). Since about 1980 the trends are diverting, with regional temperatures increasing faster than the global mean temperatures. The larger regional trend agrees with the trends given in Section 2.1 for the past decades. The difference between the regional trend and the trends of the two stations is quite small (Figure 2b). However, annual temperature differs in the order of $0.5-0.7 \mathrm{~K}$ (Figure 2c), showing that the UHI effect is larger at the downtown station than at the airport station. This was already shown by [20]. Finally, these annual differences can be correlated with population data from the city of Hamburg (Figure 2d) to search for direct human influences. 


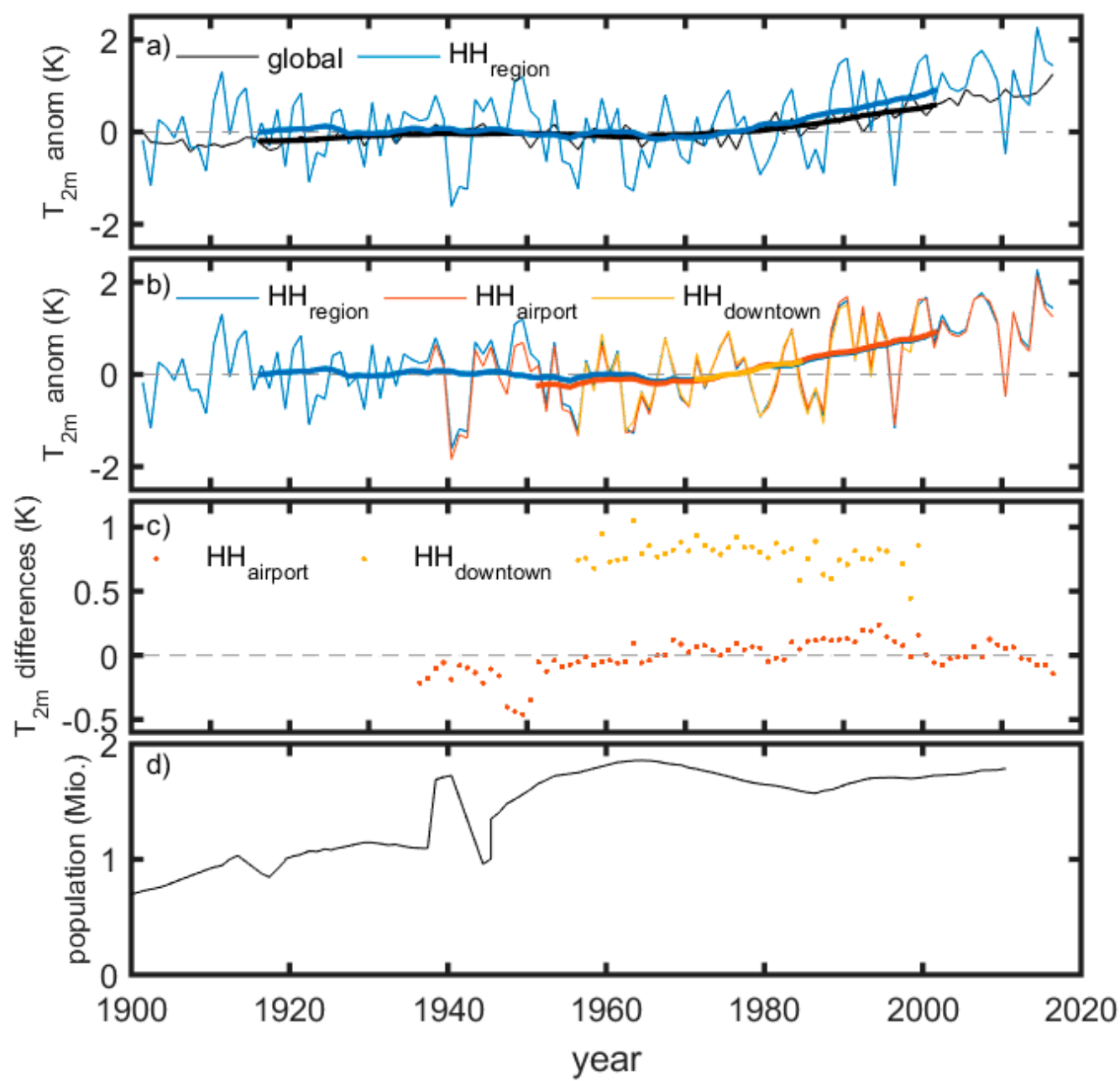

Figure 2. Annual $2 \mathrm{~m}$ mean temperature anomalies with respect to the period 1961-1990 of (a) the global mean (land-only) and the Hamburg $(\mathrm{HH})$ region (land-only, $52.58-54.5^{\circ} \mathrm{N}$ and $8.58-11.5^{\circ} \mathrm{E}$ ) based on the Climatic Research Unit Time-Series version 3.25 (CRUTS3.25) dataset [36] and (b) the Hamburg region and observations from the airport station (Hamburg-Fuhlsbüttel) and the downtown station (Hamburg-St. Pauli). Thick lines in (a,b) indicate the running 31-year mean; (c) Differences of airport station and downtown station, from the Hamburg region mean; (d) Population data from the city of Hamburg (data source: Wikipedia, accessed 21 December 2017).

In Table 2, the correlation coefficients between annual and seasonal (December, January, FebruaryDJF; March, April, May—MAM; June, July, August—JJA; September, October, November-SON) differences in the daily mean temperature, $\mathrm{T}_{\text {mean }}$, daily minimum temperature, $\mathrm{T}_{\min }$, and daily maximum temperature, $T_{\max }$, respectively, and the annual population data are presented. Surprisingly, there are significant negative correlations (annual, MAM and JJA) between $\mathrm{T}_{\text {mean }}$ differences based on the airport station, which is located within Hamburg's UHI [38]; this indicates a decrease of the urban effect with increasing population. The results for $\mathrm{T}_{\min }$ and $\mathrm{T}_{\max }$ show no significant correlations. For the downtown stations, significant positive correlations between $\mathrm{T}_{\text {mean }}$ (annual and SON) and $\mathrm{T}_{\max }$ (annual, JJA, and SON) and the population can be found. However, no significant relationship between $T_{\min }$ and population is present. The incoherent results of this analysis might result from using the population as a measure for urbanization. Other indicators such as the changing share of urban land cover [35], energy consumption [33], or night-light data [7] might be more appropriate but are not available at a sufficient time resolution (e.g., annual) or for a long enough period of time (e.g., more than 30 years). 
Table 2. Pearson correlation between differences of annual and seasonal (December, January, FebruaryDJF; March, April, May-MAM; June, July, August-JJA; September, October, November-SON) averaged $2 \mathrm{~m}$ daily mean, minimum, and maximum temperatures (station minus regional mean, see Figure 2c) and annual population data from the city of Hamburg (data source: Wikipedia, accessed 21 December 2017, see Figure 2d). Significant correlations are indicated by ${ }^{*}(\alpha=0.1)$ and ${ }^{* *}(\alpha=0.05)$.

\begin{tabular}{ccccccccccc}
\hline & \multicolumn{4}{c}{ HH $_{\text {airport }}$ (1961-2010) } & \multicolumn{5}{c}{ HH $_{\text {downtown }}$ (1961-1999) } \\
\cline { 2 - 11 } & Annual & DJF & MAM & JJA & SON & Annual & DJF & MAM & JJA & SON \\
\hline $\mathbf{T}_{\text {mean }}$ & $-0.34^{*}$ & 0.17 & $-0.49^{* *}$ & $-0.41^{* *}$ & -0.13 & $0.33^{*}$ & 0.15 & 0.02 & 0.19 & $0.48^{* *}$ \\
$\mathbf{T}_{\min }$ & 0.03 & 0.29 & 0.15 & -0.18 & -0.07 & 0.11 & -0.07 & 0.13 & 0.18 & 0.03 \\
$\mathbf{T}_{\max }$ & 0.02 & 0.15 & 0.02 & -0.16 & 0.11 & $0.44^{* *}$ & 0.17 & 0.20 & $0.34^{*}$ & $0.55^{* *}$ \\
\hline
\end{tabular}

\subsection{Impact of Climate Change on the UHI}

Due to the dependency of the UHI effect on meteorology, an impact of climate change on the urban air temperatures can be expected. By downscaling global and regional climate projections using statistical (e.g., [28,39]), dynamical [40-44], and statistical-dynamical [38,45,46] approaches it has been shown that climate change can affect the urban climate. Several studies showed that the UHI intensity might change due to the changing climate with the change signal and even the sign of change depending on the city of interest.

The variety of these results shows the need for investigating each city individually. For Hamburg, a statistical-dynamical downscaling method (SDD) [38] has been developed. It is based on the combination of an objective weather pattern classification [47,48] and $1 \mathrm{~km}$ dynamical simulations conducted with the Mesoscale Transport and Fluid Model (METRAS) [49] with REgional MOdel (REMO) and Climate Local Model (CLM) projections of the Special Report on Emissions Scenarios (SRES) A1B emission scenario. Results indicate that the average summer UHI only slightly changes at the end of the 21st century, while the number of days with large UHI intensities is expected to increase $[38,47,48]$. SDD studies with differently changed urban land cover show that depending on the change, the mean summer temperatures in Hamburg as well as Hamburg's UHI can increase (more sealed surfaces), decrease (more unsealed green surfaces), or hardly change at all (higher buildings with intense green roofs) [50].

\subsection{Interaction of Regional and Urban Signals}

Complementing the knowledge that the UHI intensity is largest during anticyclonic weather conditions, which are mostly associated with cloudless, calm, and dry conditions (e.g., [51]), Hoffmann and Schlünzen [48] investigated the dependency of Hamburg's UHI intensity on weather patterns (WPs), i.e., large-scale weather conditions associated with the large-scale atmospheric circulation, in more detail. They conducted a weather pattern classification (WPC) with a k-means based cluster analysis of $700 \mathrm{hPa}$ reanalysis data to explain variations in Hamburg's UHI intensity and obtained 7 WPs for the summer months, which differ in their large scale patterns of geopotential height, relative humidity, vorticity, and layer thickness. While the largest UHI intensities occurred during dry and anticyclonic conditions, high UHI intensities were also found for other WPs. Arnds et al. [52] also found a statistical relationship between measurements of urban-rural temperature differences from several urban stations in Hamburg and the objective weather types provided by the German Meteorological Service (DWD). The strength of these relationships varied considerably for different stations and seasons. A study by Jacobson and ten Hoeve [53] showed that urban areas can also have an impact on regions that are distant from urban areas, which suggests an impact on the large-scale atmospheric circulation. It is, however, not yet clear which processes are causing these impacts. Therefore, it is necessary to investigate possible impacts of urban areas on large-scale meteorological fields as well as on teleconnection mechanisms in the global climate system. 


\section{Other Meteorological Parameters}

\subsection{Surface Temperature}

In addition to the air temperature UHI, the surface temperature UHI (SUHI) characterizes the urban environment, in particular its modifications of the local energy budgets. A common way to determine the SUHI is the use of thermal remote sensing data. To date, many SUHI studies are based on a single acquisition from a satellite. Since land surface temperature (LST) is a highly variable quantity in both space and time, this approach results in a high degree of randomness. Typically, comparably cloud free scenes are chosen, which severely limits the availability and results in differences in the seasonal coverage and a bias towards specific WPs (see Section 2.5 for dependence of UHI on WPs). Inevitably, the results of such an SUHI analysis will depend on the chosen acquisition date due to relevant influences including atmospheric conditions (radiation, previous cloud cover, etc.), soil conditions (especially soil moisture), phenology, and observation conditions such as viewing time and angle [54].

Therefore, in [55,56], a time series analysis approach utilizing long satellite archives was proposed as an alternative approach to study the SUHI. The basic idea is to use all available acquisitions per pixel to fit a seasonal LST model and, thus, split the time series into a mean annual temperature cycle and short-term fluctuations. Besides various other potential applications, including geothermal energy [57], water masking [58], ecological modelling [59], topo-climatology [60], and LST downscaling [61-64], it has mainly been used to study and provide a more robust description of the SUHI [65-67]. Figure 3 shows an aerial image and the mean annual surface temperature at 13:30 local solar time from Moderate Resolution Imaging Spectroradiometer (MODIS) Aqua LST data for Hamburg, Germany. The mean annual SUHI (under cloud-free conditions) is clearly visible, while the forested areas and some water bodies appear as sinks. This first approach has been followed in several case studies, including Dutch and Belgium cities [68], for Beirut, Lebanon [69], Sao Paulo, Brazil, Mumbai, India [56], and five cities on five continents in [65].

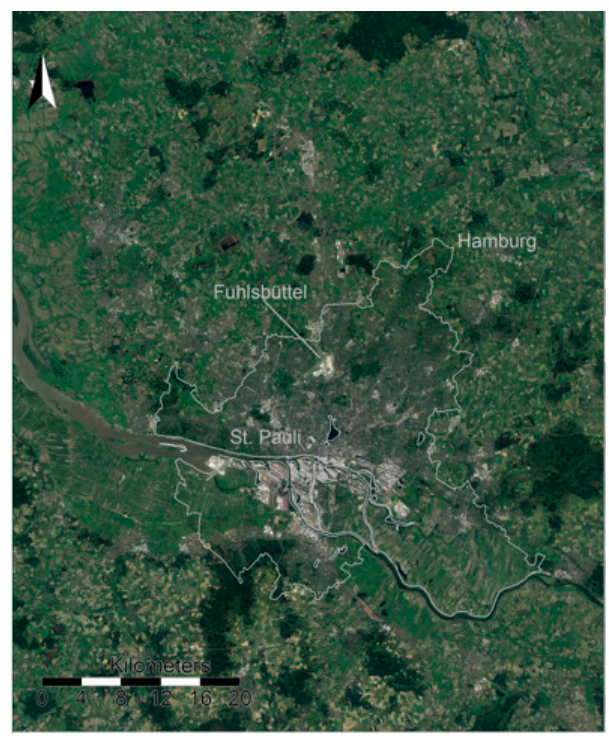

(a)

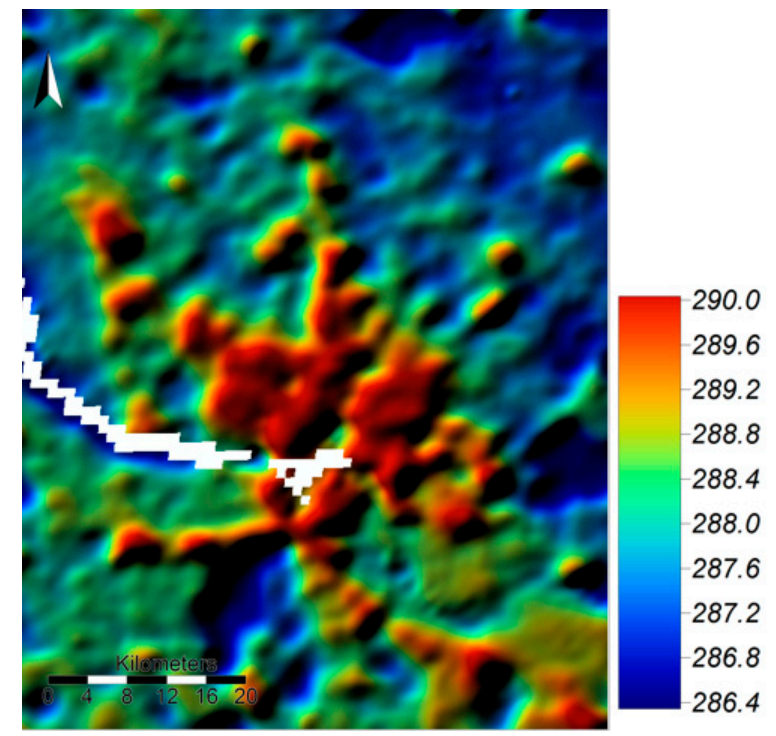

(b)

Figure 3. (a) Aerial image of the city of Hamburg. Google Earth; (b) Mean annual surface temperature (K) from MODIS Aqua at 13:30 local solar time from 2011-2015 under clear sky conditions.

Moreover, the annual cycle approach allows consistent comparison of the SUHI of different cities (Table 3) as well as studying its temporal dynamics [54]. Based on the approximated annual course of day and nighttime surface urban heat island intensity (SUHII) for Hamburg (MODIS Aqua, 2011-2015), 
the SUHII is larger on average during the daytime than it is during the nighttime; this is contrary to the atmospheric UHI with its maximum intensity in the evening and early night. Around the winter solstice, the SUHI is larger at nighttime than at daytime. This seasonal variation of the SUHII underlines the necessity of multi-temporal data in SUHI studies. In addition, analysis of the residuals and their spatial patterns allow detection and attribution of changes and trends by comparison with spatial patterns of potential causing factors such as urbanization and climate change. The currently available time series do not have sufficient length for climatological analysis, but homogenized multi-sensor datasets will become available soon.

Table 3. Modelled surface urban heat island intensities (SUHII) for Hamburg, Hannover, and Berlin from MODIS Aqua from 2011-2015. Mean annual maximum and mean SUHII (K) at daytime (13:30 local solar time) and nighttime (01:30 local solar time) acquisition.

\begin{tabular}{cccc}
\hline City & Hamburg & Hannover & Berlin \\
\hline daytime (mean) & 1.7 & 1.9 & 2.4 \\
daytime (max) & 3.3 & 3.5 & 4.1 \\
nighttime (mean) & 1.2 & 1.2 & 1.4 \\
nighttime (max) & 1.8 & 1.7 & 1.9 \\
\hline
\end{tabular}

\subsection{Wind}

Observed wind patterns and storminess show a large decadal variability at the regional scale across Europe and Germany, such that significant long-term trends are difficult to detect [70]. Numerical modelling studies use a variety of methods, which makes it difficult to compare results and assess effects of changing global climate conditions [71]. Some studies agree with a northwards shift of northern hemisphere storm tracks and intensity since 1970 [72,73]. However, studies on regional changes of storm tracks and the resulting characteristics of severe storms are subject to large uncertainties [70]. Recent CMIP5 simulations project an extension eastwards of the North Atlantic storm track towards central Europe and the British Isles [74]. The comprehensive review of Feser et al. [71] on studies covering the North Atlantic and northern, north-western, and central Europe shows large agreement that the intensity of winter storms will increase in all these regions over the 21st century.

The wind speed has an annual cycle, for Hamburg with larger wind speeds in winter than in summer [20]. This is a result of the regional climate of the region where the pressure gradients are, in general, larger in winter than in summer. Furthermore, a diurnal cycle adds to this with larger wind speeds at daytime than in the night and a frequently observed low level jet (Figure 4 in [75]). The area-averaged mean wind speeds are decreased by the urban land cover. High obstacles and aerodynamically rough surfaces as well as trees modify the average wind speed in the urban areas considerably. The very local character of urban winds is illustrated exemplarily by data from a complex boundary layer wind tunnel experiment [76]. While over smooth water areas, the wind speed is relatively high close to the surface (Figure 4 left), these speeds are reduced in the large spaces between building (Figure 4 center) and are much smaller than outside the canopy layer between buildings (Figure 4 right). Thus, the wind speeds are very locally changed and average values are smaller than away from buildings. However, not only the spatial differences but also the temporal variability is large; short time wind values ( wind gusts) locally can be above the values observed outside the urban canopy, but most often they are much lower. The gustiness in urban areas is larger than outside. Due to the buildings' impacts, the wind speed is reduced on average (factor of 5-10), however, local flow channeling can occur, especially within street canyons facing the larger water areas (e.g., a wide river). 

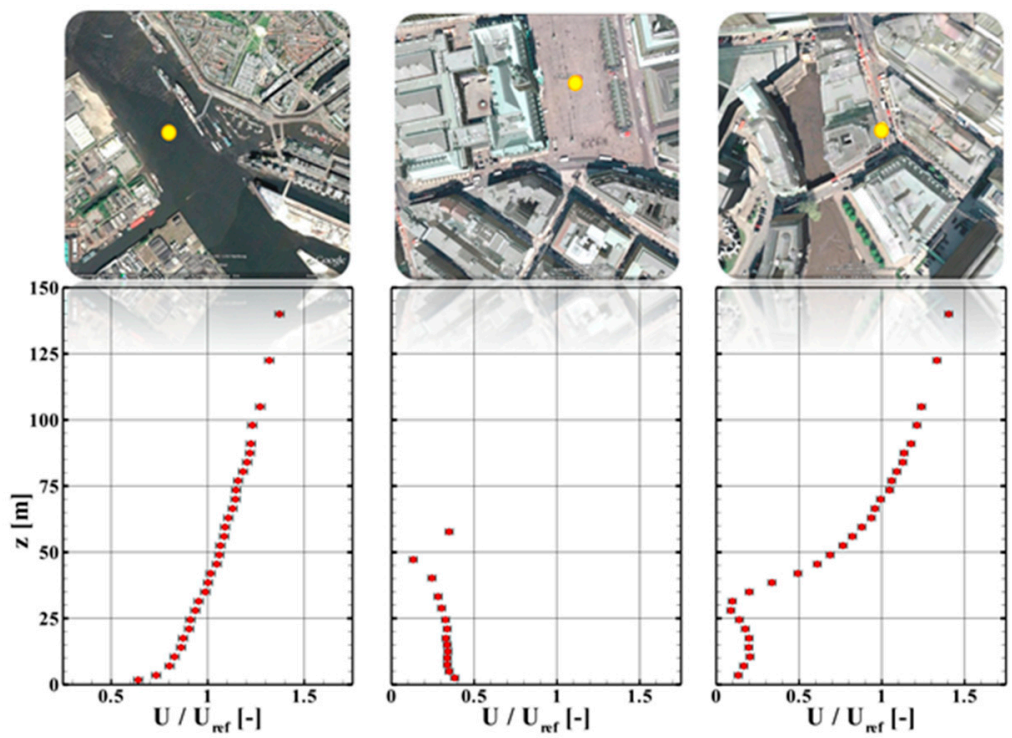

Figure 4. Exemplary average non-dimensional wind profiles as determined by physical modelling (boundary layer wind tunnel data) for different places of a city. $U_{\text {ref }}$ is the wind speed taken from an undisturbed profile at $30 \mathrm{~m}$ above ground (left figure).

Changes in the wind field are not restricted to wind speed but also concern wind direction; together with the wind speed changes, wind directions reach into the atmosphere above the roof level. Figure 5 shows, for two chosen wind directions, the local impacts of buildings on flow directions at a height of at least $30 \%$ above the average building height. Mean wind deflections are up to $\pm 5^{\circ}$. Within the urban canopy, the directional changes are even larger, resulting in a flow channeling parallel to the street canyon. While regional flow patterns vary in a wide range, the urban impacts are completely dependent on the urban land cover, and persistent pattern changes occur for each wind direction. These are at least in the range of climate induced wind changes (above roof level), but are much larger within the street canyon. Thus, the regional wind fields are completely changed (in some cases within the urban canopy with not only smaller but also opposite wind directions).
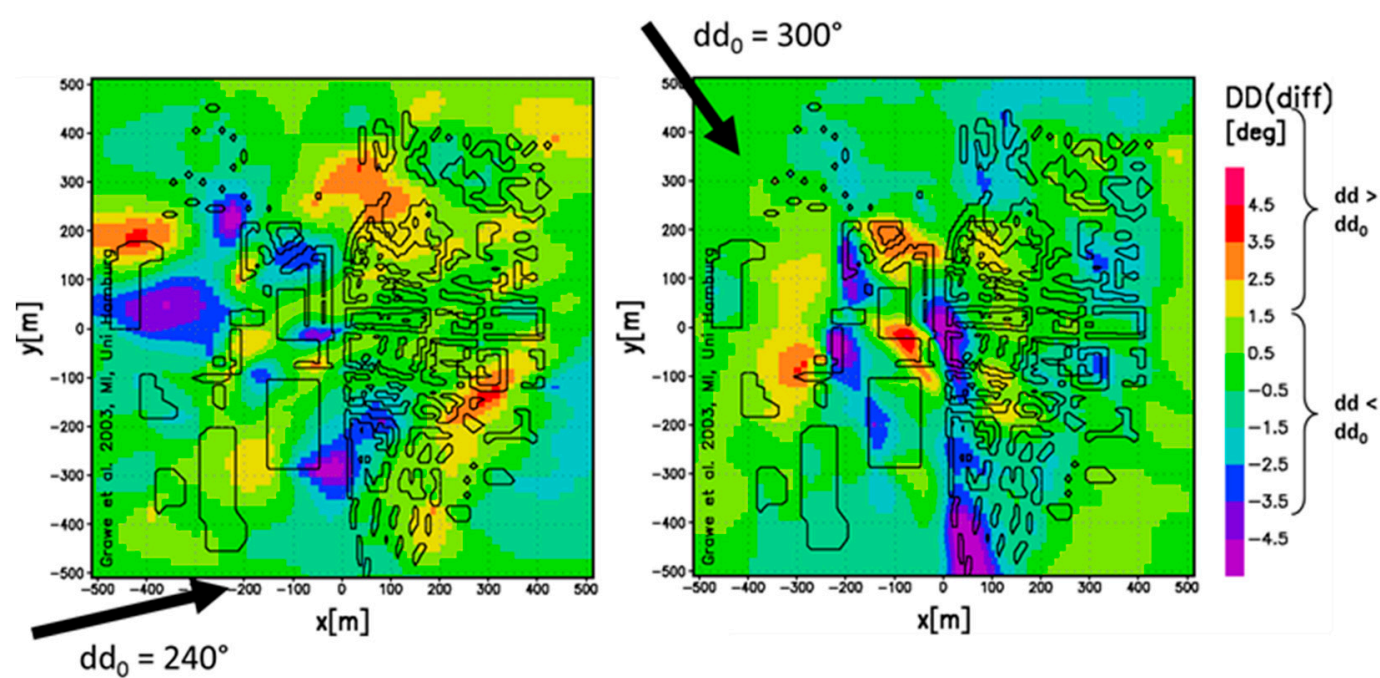

Figure 5. Average change in wind direction for two main flow directions at a height of $42 \mathrm{~m}$ with a maximum building height of $32 \mathrm{~m}$ at about $\mathrm{x}=\mathrm{y}=0 \mathrm{~m}$; all other buildings are $20 \mathrm{~m}$ and lower, as simulated in the wind tunnel for different places in a city. 


\subsection{Precipitation}

The average annual precipitation across Europe shows no significant changes since 1960 according to the E-OBS observation dataset [10], but on a sub-continental scale, significant changes are detected [77]. Annual precipitation has increased over northern Europe up to $70 \mathrm{~mm}$ per decade (western Norway), whereas annual precipitation has decreased in parts of southern Europe by up to $90 \mathrm{~mm}$ per decade (Iberian Peninsula). Changes in large-scale circulation patterns play a key role in the observed changes in precipitation [78,79]. Based on the EURO-CORDEX multi-model ensemble, the ensemble mean for the RCP8.5 shows a significant increase in large parts of central and northern Europe of up to $25 \%$ and a decrease in southern Europe. The spatial patterns of the changes are very similar for RCP4.5 but less pronounced [12].

Long-term observational records show a general increase of annual mean precipitation in Germany. For the time period 1881-2014, the trend related to 1961-1990 shows a significant increase of $+10 \%$, with the largest increase of $26 \%$ in winter and a small but not significant decrease in summer $(-0.6 \%)$ [13]. Climate projections for the 21st century simulate further increases of winter precipitation, whereas for summer, no robust changes can be derived. Based on the EURO-CORDEX multi-model ensemble, the projected precipitation changes at the end of the century (relative to 1971-2000) are in a range of $-3 \%$ to $+17 \%$ for RCP 4.5 and $+8 \%$ to $+32 \%$ for RCP 8.5 [15].

The observed mean annual precipitation sum at station Hamburg-Fuhlsbüttel is $773 \mathrm{~mm}$ per year (calculated on the basis of data from [16]). The annual precipitation values show large differences from year to year. The minimum annual precipitation sum occurred in 1959 with $392 \mathrm{~mm}$. The maximum annual precipitation sum occurred in 2007 with $1072 \mathrm{~mm}$. For the larger area of the Metropolitan region of Hamburg, most EURO-CORDEX simulations project a further increase in winter precipitation in a range of $-4 \%$ to $+32 \%$ towards the end of the 21st century relative to 1971-2000 [17]. For summer, there is no model agreement on projected precipitation changes; about the same number of simulations show increased or decreased precipitation values. One single simulation projects $+40 \%$, and all other simulations are in the range of $-20 \%$ and $+20 \%$.

Due to the UHI effect, emissions of aerosols, which act as cloud condensation nuclei, and increased surface roughness, rainfall can be enhanced downwind of urban areas (e.g., [80,81]). Schlünzen et al. [20] found significant increases in daily precipitation downwind from Hamburg analyzing long-term precipitation measurements in the metropolitan region. However, they could not attribute these increases to specific urban-related effects and some stations did not show significant changes. Especially, the impact of the orography could not be ruled out as causing effect. Schoetter [82] conducted dynamical simulations with METRAS for 72 heavy precipitation events ( $>25 \mathrm{~mm} /$ day) in Hamburg during the summer season. The results showed a significant impact of the orography on heavy precipitation over Hamburg. The impact of the urban structure is dependent on the weather situation and, therefore, it is not significant when averaged over the 72 heavy precipitation events. Regional climate projections for the period 2021-2050 based on RCP4.5 conducted with the Regional Climate Model (RCM) COSMO model in CLimate Mode (CCLM) show a stronger increase in heavy precipitation days ( +1 day/year) over Hamburg compared to the rest of the metropolitan region [29].

\subsection{Solar Radiation}

Overall, there is only a little information concerning the regional change of solar radiation in northern Germany and hardly any about the differences between the urban area and the surrounding region. The best available data to analyze trends in solar radiation is the sunshine duration, which can be used from around 1950 on [83]. They reported a mean annual sunshine duration for the years 1971-2000 of 1585 hours. Interestingly, this is slightly higher than the sunshine duration in the surrounding regions (between 1500 and $1560 \mathrm{~h}$, Figure 2.20 in [83]). Schönwiese and Janowitz [84] analyzed the linear trends of the sunshine duration in the years 1951-2000 and 1971-2000 for northern Germany. It may be worth noting the impact of the Scandinavian mountains, which cause high northern air currents connected to strong lows. The sinking air in the lee of the mountains causes 
dry weather with few clouds. For the Hamburg region, the observed trend is slightly negative; it is between 0 and -50 days per year for the period from 1951 on and between -50 and -100 days per year in the period from 1971 on. However, both trends are not significant.

Brümmer et al. [26] investigated the down welling short- and long-wave radiation at the Hamburg Weather mast for the time period 1995-2011. They analyzed the mean annual and diurnal cycle, but due to the short time period they did not examine trends in radiation. The mean annual incoming short-wave radiation flux amounts to $120 \mathrm{~W} \mathrm{~m}^{-2}$, with maximums in May, June, and July (values between 155 and $159 \mathrm{~W} \mathrm{~m}^{-2}$ ). Integrated over the whole year, the incoming radiation energy amounts to $1013 \mathrm{kWh} \mathrm{m}^{-2}$, which is $56 \%$ of the maximum possible amount for clear sky.

For the future, solar radiation is projected to statistically significantly decrease in large parts of the world up to the mid-21st century, based on CMIP5 models. However, exceptions are, inter alia, most parts of Europe with positive trends [85] and with no definite signal for northern Germany in the regarded models [86].

\subsection{Human Comfort}

The impact of the described changes in radiation, temperature, humidity, and wind on thermal comfort can be characterized by so-called thermal indices. These summarize the effects of the individual meteorological parameters on thermal comfort or stress into one quantity by using weighted equations or heat balance models [87]. In total, more than 165 thermal indices have been developed [88] with different characteristics and application areas [89,90].

A commonly used index is the Physiological Equivalent Temperature (PET, [91,92]), a rational index based on the heat balance of the human body. It uses fixed clothing insulation and is, therefore, independent of personal behavior. Globally, an overall increase of PET is projected for 2070-2100 for different emission scenarios for both summer and winter [93]. In many regions, PET changes more strongly than air temperature, indicating that for impact assessment of climate change on thermal stress, biometeorological indices should be used. Similar results have been obtained for the perceived temperature [94].

To estimate past regional changes in PET in northern Germany, PET has been calculated from air temperature, relative humidity, wind speed, and mean radiant temperature $\left(T_{m r t}\right)$ for the airport weather station at Hamburg-Fuhlsbüttel operated by the DWD. $\mathrm{T}_{\mathrm{mrt}}$ was calculated by the algorithm described by ref. [95], Staiger personal communication which is based on air temperature, humidity, wind speed, cloudiness, and Linke turbidity factor. For cloudless conditions, the European Solar Radiation Atlas (ESRA) model $[96,97]$ with changed coefficients [98] is used. Clouds are accounted for by the cloud modification factor suggested by [99] and diffuse shortwave is parameterized following [100]. Downward longwave radiation is modelled according to [101] with adjusted coefficients [102], and upward longwave radiation is parameterized using the Bowen ratio [103]. This configuration was found to perform best with a limited number of inputs [95]. Details on the calculation method can be found in [104].

Figure 6 shows monthly relative frequencies of daytime PET classes for 1956-1985 and 1986-2015 (Figure 6 top left and right, respectively) and differences in relative frequency between the two periods at the airport weather station. An annual cycle of PET values with cold conditions during winter and no stress to heat stress conditions in summer is obvious. Between the two periods, PET has statistically significantly changed (Figure 6 bottom); classes of higher PET values are more frequent in 1986-2015 than before. The smallest changes are experienced in June (not significant), September, and October; the strongest increases in heat stress are to be expected in July and August. A closer analysis of changes in the used meteorological parameters [104] indicates that increased air temperatures and increased $\mathrm{T}_{\mathrm{mrt}}$ in all months are responsible for the found changes.

In urban areas, PET depends on urban morphology; narrow streets provide, on the one hand, side shading and, therefore, decrease PET, but on the other hand, they decrease wind speed which 
increases heat stress. Consequently, for different urban morphologies, different increases in heat stress are projected in terms of PET for both Gothenburg [105] and different cities in the Netherlands [106].
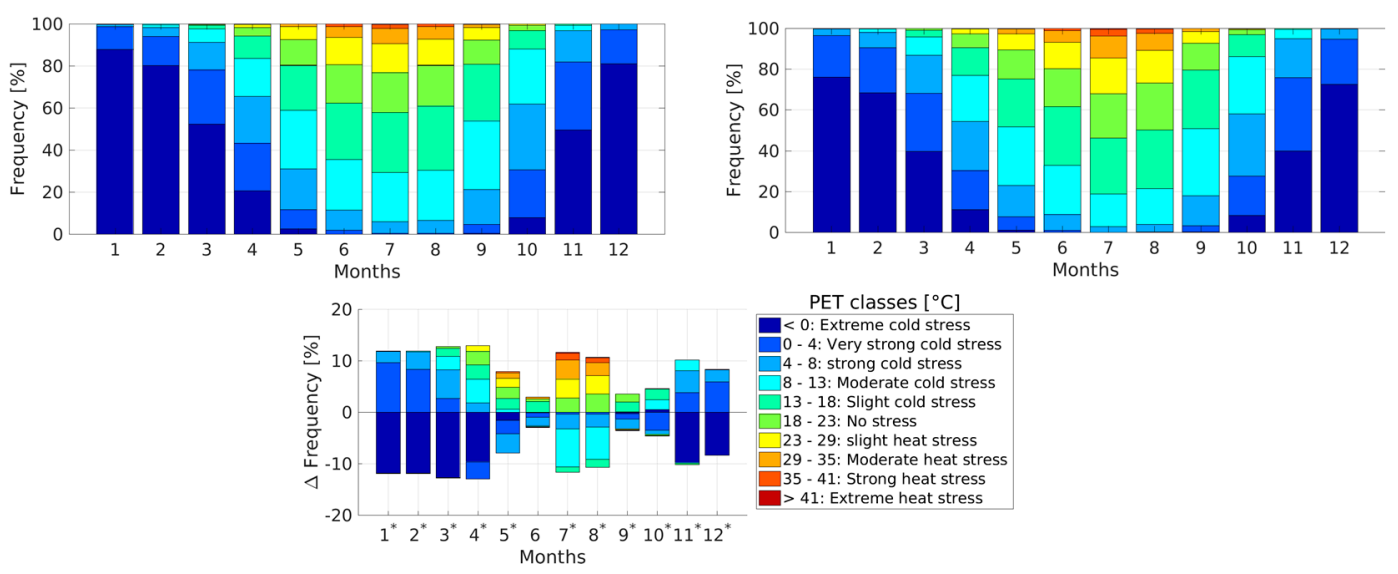

Figure 6. Frequency of different Physiological Equivalent Temperature (PET) classes during the day (06:00 to 22:00) for two 30-year-periods (top left: 1956-1985; top right: 1986-2015) and changes in frequency of different classes between the two periods, e.g., PET(1986-2015)-PET(1956-1985) (bottom). Statistically significant monthly changes in PET distributions based on a Chi-squared test with a significance level of $5 \%$ are indicted by asterisk * at the according month.

\subsection{Humidity and Evapotranspiration}

The regional and global climate change signal in humidity and evapotranspiration is physically linked to air temperature and solar radiation, on the one hand, and surface water availability, on the other hand. Simulations indicate that groundwater acts as a source for soil water in near-surface layers when the groundwater depth lies within a critical zone. Moreover, the surface energy flux partitioning, especially the latent heat fluxes, depend on groundwater table depth [107]. Therefore, changes in groundwater, as they were observed in the past and are predicted for the future, will also affect topsoil water content and, thus, evaporation at the local scale. Climate variability and change influences groundwater systems both directly, through replenishment and recharge, and indirectly, through changes in the anthropogenic use of groundwater and land-use change. There is great consensus on changes in all regions in precipitation (locally highly variable) and temperature extremes (projected to increase). On a global scale, two thirds of the irrigated area in 1995 will be subjected to increased water requirements for irrigation by 2070 . However, demands vary at a very local scale. In Europe, potential recharge projections demonstrate strong latitudinal dependence on the direction of the climate change signal, with substantial reduction in southern Europe and increases of groundwater recharge in northern Europe [108]. Germany will most likely not be affected significantly by groundwater level changes in the future, given its location in a temperate climate. Apart from that, the modification of soil function itself and, therefore, the change in its evapotranspiration function, can be qualitatively derived from available estimates and modeling for individual regions. Yet, they are difficult to quantify. Moreover, the few long-term field measurements of soil moisture and temperature give only very limited information about the direction and scale of the changes that are to be expected [109].

On the urban scale, modifications in surface water availability are mainly due to the high percentage of sealed surface, with additional effects of modified replenishment from groundwater [110]. The widespread urban sealing affects the natural climate functions of soils by diminishing the amount of water that infiltrates and by increasing run-off. Even more, sealing obstructs the exchange between soil and atmosphere [111-113], so a local air temperature reduction function of soils by evapotranspiration is no longer given. Apart from this urban characteristic, a study regarding the local impact of groundwater table depth on urban air temperature [25] suggests that local topsoil moisture can be regarded as one significant impacting factor for the daytime increase of air temperature. It was 
shown that the normalized topsoil water content (upper $10 \mathrm{~cm}$ ) is correlated to the daytime span of air temperature with an explained variance of up to $17 \%$ for situations meeting appropriate conditions for evapotranspiration.

Several studies focus on air temperatures reducing urban parks and unsealed vegetated areas and their relevance for nearby surroundings [111,112,114-119]. Nevertheless, the climate influencing efficiency of urban soils and vegetation is coupled. Lowered soil water contents of urban areas (due to increased run-off and hampered infiltration) affect the cooling efficiency of a city's vegetation. For trees in urban areas, a reduced soil water availability [120] together with an elevated evaporative demand [121] increase the risk of drought stress. If the transpiration requirement exceeds root water uptake, stomatal closure results in a lowered transpiration rate [122] and, thus, in a reduced cooling effectiveness [123]. However, despite the important role of soil water availability, the number of studies focusing on its direct impact on urban tree transpiration is still low. Rahman et al. [124] found that transpirational cooling of small-leaved lime (Tilia cordata mill.), one of the most common urban tree species in temperate climates, was limited in times of soil water shortage. In contrast, a study on mature pedunculate oaks (Quercus robur L.) growing in the city center of Hamburg revealed that an elevated evaporative demand and a reduced soil water availability in the uppermost $80 \mathrm{~cm}$ of the soil did not limit tree transpiration, probably due to stress avoidance by root water uptake at greater soil depths [125]. Moreover, it was shown that nighttime transpiration of the studied oaks accounted for up to $22 \%$ of the daily total. Consequently, transpirational cooling of the oak trees was not limited even in times of moderate drought and could be provided during both daytime and nighttime conditions.

A precise value for the share of transpiration from vegetation and soil water evaporation on urban local climate modifications cannot be given. However, a high number of studies, as already stated above, allow for the conclusion that soils, groundwater, and plants do contribute to the formation of a specific local urban climate.

\section{Conclusions and Outlook}

After reviewing and aggregating research results for numerous meteorological parameters, the answer to the initial question of whether local meteorological phenomena can be assigned to either general climate effects or urban land cover outcome is: it depends. For some considered parameters, the overall global and/or regional climate change signals can be set apart from the local effects induced by urban areas. Yet for others, the contribution of each to the measured signal is not determinable; for some the effect seems small.

For air temperature, it is possible to separate local changes from the regional signal, as especially, the characteristic effects like UHI have a diurnal and seasonal cycle, and are more pronounced during certain times of the day (afternoon, evening) and year (summer). A good characteristic variable to trace recent changes in local climate parameters are threshold days. They allow for the quantification of the part caused by local urban land cover in contrast to an overall global or regional change or trend in climate. Using the population as a measure for urbanization and correlating that to urban air temperature trends in the past, however, did not result in detection of a considerable relation.

For local surface temperatures (LST), a distinction is generally possible. Differences in surface temperature are very locally induced. LST is well suited to distinguish local land surface and larger scale atmospheric changes since it allows simultaneous and spatially extensive observation of urban and rural areas over time. While the existing time series already allow identification of abrupt changes associated with surface-cover change, extended time series and improved homogenization between sensors will soon also allow detection of trends at climatic time scales. The analysis is, however, restricted to cloud free pixels.

In the case of wind, a determination is possible, giving a clear urban signal. Observations and projections at the global/regional scale are highly variable, but overall suggest small changes in wind direction and speed, for e.g., northern Germany. Yet, on the local scale, impacts of the urban land cover can be found from above the buildings (up to $30 \%$ above building height, a clear signal in wind speed 
and direction). In the urban canopy layer, the effects are very local, reaching small reductions at open places to a factor of 5 in a street canyon. The wind direction is slightly but persistently impacted above roof level and completely depends on the street orientation versus the flow direction above roof level within the urban canopy.

Precipitation is highly variable in space. The climatic regional trend throughout Europe varies, as well as locally, precipitation amount and timing can vary within a few hundred meters. Therefore, an assignment to regional or local effects cannot be made. However, a few general trends can be derived and projections for the future show tendencies, e.g., precipitation has increased during wintertime for Germany in the recent past and will most likely continue in the future. Furthermore, urban specific effects are possible, like enhanced precipitation in downwind areas; in studies for Hamburg these effects could not directly be attributed to urban effects and could not be distinguished from modifications in precipitation at the regional scale. This local change can thus be very contrary for different areas, and orographic effects seem to be more relevant.

No significant effects can be observed for urban modifications in sunshine duration, hence, nor in solar radiation. In terms of thermal comfort, a significant increase in frequency of higher PET values was observed for Hamburg, caused by observed changes in air temperature (see above) and changes in mean radiant temperature $\left(\mathrm{T}_{\mathrm{mrt}}\right)$. Increasing $\mathrm{T}_{\mathrm{mrt}}$ values but slightly decreasing sunshine durations (above) seem to contradict. However, $\mathrm{T}_{\mathrm{mrt}}$ is a derived variable that includes, besides direct radiation, also diffuse shortwave as well as longwave radiation and human related parameters, such as albedo or projection factor, which mask the effect of sunshine duration alone. Furthermore, $\mathrm{T}_{\mathrm{mrt}}$ is derived from parameterizations using cloud fraction and standard meteorological inputs and, therefore, does not include sunshine duration directly. Urban materials and morphologies alter thermal comfort changes compared to rural areas.

A very specific local signal is found in evapotranspiration from plants and soils. This is induced by the high urban surface sealing ratio and thus limited water availability. This is a very small-scale effect affecting the local humidity and is completely related to the urban morphology and materials.

This compilation of results shows that for some climate parameters a qualitative distinction is feasible, whilst a quantitative assignment of the effect to global/regional change or to urban land cover can hardly be performed. In urban environments, especially surface temperature, air temperature, and wind are locally modified; the common urban heat island effect is clearly morphology and material induced (SUHI) and impacted (UHI), the wind velocity is influenced by the land cover, reducing overall wind speeds and increasing gustiness.

Certainly, the robustness of the assignment to one single cause for a locally measured phenomenon, as well as the general determination of a value by global/regional or local effects, is highly dependent on the meteorological parameter being looked at. It also depends on the impacting factor's accuracy itself: How probable is the increase of $X$ degrees in air temperature due to climate change? To which degree does the building's façade influence local wind velocity at a specified point? Thus, the quality of predictions is limited by the probability and preciseness of the prediction of the external influences.

Most probably, there are effects of interactions between the global and regional signals and urban land cover induced effects. In some cases, climate change signals and urban land cover induced effects reinforce each other, to be observed especially in the context of the nighttime urban heat island as air temperature increases in the long term and fosters a higher number of extremes. For other parameters, the effects conceivably counteract each other. Even more, some locally induced changes in one parameter might also affect one another on a larger scale. For example, the reduction of humidity due to less water availability at the surface leads to a decrease in latent heat fluxes and, thus, to a higher air temperature.

The observations and simulations conducted for Hamburg are transferable to other regions to a limited extend, for instance, mid-latitude cities with oceanic climate and only few high-rise buildings. However, the results to SUHI and wind effects of urban areas are very generic and transferable to other cities. There are also several practical applications of the gained knowledge. Being able to identify 
parameters which are more sensitive to local strategies (surface temperature, air temperature, wind speed, ground water limitations) allows for the counteracting of the local symptoms of climate change effects more systematically and in a more focused manner. Other parameters which do not show comparably pronounced urban effects (precipitation) need to be addressed in changing the urban fabric by introducing climate change adaptation measures.

Further work should asses for other cities, especially located in other climate zones, if the found qualitative attributions are true in general. In addition, parameters like precipitation or thermal comfort need to be considered in greater detail.

Acknowledgments: This research is supported through the Cluster of Excellence "CliSAP" (EXC177) funded through the German Science Foundation (DFG), the Federal Ministry of Education and Research (BMBF) funded project KLIMZUG-NORD and the City of Hamburg funded research project UrbMod (Cities in Change-Development of a multi-sectoral urban development impact model). The program to estimate the mean radiant temperature from meteorological measurements was provided by H. Staiger.

Author Contributions: Sarah Wiesner compiled knowledge on UHI measurements and humidity, wrote the according paragraph, introduction, and conclusion, revised all sections and assembled the paper; Benjamin Bechtel compiled knowledge on surface temperature and wrote the according paragraph; Jana Fischereit compiled knowledge on human comfort and wrote the according paragraph; Verena Gruetzun compiled knowledge on solar radiation and wrote the according paragraph; Peter Hoffmann compiled knowledge on urban heat island and urban impact on precipitation, carried out statistic calculations, and wrote the according paragraphs; Bernd Leitl provided the in-street canyon wind analyses; Diana Rechid compiled knowledge on global and regional air temperature, wind and precipitation, and wrote the according paragraph; K. Heinke Schlünzen compiled knowledge on wind, wrote the according paragraph, set up the general concept, and harmonized the paper; Simon Thomsen compiled knowledge on vegetation and wrote the according paragraph.

Conflicts of Interest: The authors declare no conflict of interest.

\section{References}

1. IPCC. Climate Change 2013: The Physical Science Basis. Contribution of Working Group I to the Fifth Assessment Report of the Intergovernmental Panel on Climate Change; Stocker, T.F., Qin, D., Plattner, G.-K., Tignor, M., Allen, S.K., Boschung, J., Nauels, A., Xia, Y., Bex, V., Midgley, P.M., Eds.; Cambridge University Press: Cambridge, UK, 2013; ISBN 978-1-107-66182-0.

2. Chapman, S.; Watson, J.E.M.; Salazar, A.; Thatcher, M.; McAlpine, C.A. The impact of urbanization and climate change on urban temperatures: A systematic review. Landsc. Ecol. 2017, 32, 1921-1935. [CrossRef]

3. Schlünzen, K.H.; Grawe, D.; Bohnenstengel, S.; Schlüter, I.; Koppmann, R. Joint modelling of obstacle induced and mesoscale changes-Current limits and challenges. J. Wind Eng. Ind. Aerodyn. 2011, 99, 217-225. [CrossRef]

4. Von Szombathely, M.; Albrecht, M.; Antanaskovic, D.; Augustin, J.; Augustin, M.; Bechtel, B.; Bürk, T.; Fischereit, J.; Grawe, D.; Hoffmann, P.; et al. A Conceptual Modeling Approach to Health-Related Urban Well-Being. Urban Sci. 2017, 1, 17. [CrossRef]

5. Morice, C.P.; Kennedy, J.J.; Rayner, N.A.; Jones, P.D. Quantifying uncertainties in global and regional temperature change using an ensemble of observational estimates: The HadCRUT4 data set. J. Geophys. Res. 2012, 117. [CrossRef]

6. Karl, T.R.; Arguez, A.; Huang, B.; Lawrimore, J.H.; McMahon, J.R.; Menne, M.J.; Peterson, T.C.; Vose, R.S.; Zhang, H.-M. Possible artifacts of data biases in the recent global surface warming hiatus. Science 2015, 348, 1469-1472. [CrossRef] [PubMed]

7. Hansen, J.; Ruedy, R.; Sato, M.; Lo, K. Global surface temperature change. Rev. Geophys. 2010, 48. [CrossRef]

8. Simmons, A.J.; Berrisford, P.; Dee, D.P.; Hersbach, H.; Hirahara, S.; Thépaut, J.N. A reassessment of temperature variations and trends from global reanalyses and monthly surface climatological datasets. Q. J. R. Meteorol. Soc. 2017, 143, 101-119. [CrossRef]

9. Schurer, A.P.; Mann, M.E.; Hawkins, E.; Tett, S.F.B.; Hegerl, G.C. Importance of the pre-industrial baseline for likelihood of exceeding Paris goals. Nat. Clim. Chang. 2017, 7, 563-567. [CrossRef] [PubMed]

10. Haylock, M.R.; Hofstra, N.; Klein Tank, A.M.G.; Klok, E.J.; Jones, P.D.; New, M. A European daily high-resolution gridded dataset of surface temperature and precipitation for 1950-2006. J. Geophys. Res. 2008, 113. [CrossRef] 
11. Van der Schrier, G.; van den Besselaar, E.J.M.; Klein Tank, A.M.G.; Verver, G. Monitoring European average temperature based on the E-OBS gridded data set. J. Geophys. Res. 2013, 118, 5120-5135. [CrossRef]

12. Jacob, D.; Petersen, J.; Eggert, B.; Alias, A.; Christensen, O.B.; Bouwer, L.M.; Braun, A.; Colette, A.; Déqué, M.; Georgievski, G.; et al. EURO-CORDEX: New high-resolution climate change projections for European impact research. Reg. Environ. Chang. 2014, 14, 563-578. [CrossRef]

13. Kaspar, F.; Mächel, H. Kapitel 3-Beobachtung von Klima und Klimawandel in Mitteleuropa und Deutschland. In Klimawandel in Deutschland: Entwicklung, Folgen, Risiken und Perspektiven; Brasseur, G., Jacob, D., Schuck-Zöller, S., Eds.; Springer Spektrum: Berlin, Germany, 2016.

14. Deutschländer, T.; Mächel, H. Kapitel 6-Temperatur inklusive Hitzewellen. In Klimawandel in Deutschland: Entwicklung, Folgen, Risiken und Perspektiven; Brasseur, G., Jacob, D., Schuck-Zöller, S., Eds.; Springer Spektrum: Berlin, Germany, 2016.

15. Jacob, D.; Kottmeier, C.; Petersen, J.; Rechid, D.; Teichmann, C. Kapitel 4-Regionale Klimamodellierung. In Klimawandel in Deutschland: Entwicklung, Folgen, Risiken und Perspektiven; Brasseur, G.P., Jacob, D., Schuck-Zöller, S., Eds.; Springer Spektrum: Berlin/Heidelberg, Germany, 2016; ISBN 9783662503973.

16. DWD Climate Data Center (CDC). Historical Daily Station Observations (Temperature, Pressure, Precipitation, Wind, Sunshine Duration, etc.) for Germany, version v004; DWD Climate Data Center: Offenbach, Germany; Available online: ftp:/ /ftp-cdc.dwd.de/pub/CDC/ (accessed on 21 December 2017).

17. Meinke, I.; Rechid, D.; Tinz, B.; Maneke, M.; Lefebvre, C.; Isokeit, E. Klima der Region-Zustand, bisherige Entwicklung und mögliche Änderungen bis 2100. In Hamburger Klimabericht_Wissen über Klima, Klimawandel und Auswirkungen in Hamburg und Norddeutschland; von Storch, H., Claussen, M., Eds.; Springer: Berlin/Heidelberg, Germany, 2017; ISBN 978-3-662-55379-4.

18. Oke, T.R. The energetic basis of the urban heat-island. Q. J. R. Meteorol. Soc. 1982, 108, 1-24. [CrossRef]

19. Von Storch, H.; Claussen, M. Klimabericht für die Metropolregion Hamburg; Springer: Berlin, Germany, 2011; ISBN 9783642160349.

20. Schlünzen, K.H.; Hoffmann, P.; Rosenhagen, G.; Riecke, W. Long-term changes and regional differences in temperature and precipitation in the metropolitan area of Hamburg. Int. J. Climatol. 2010, 30, 1121-1136. [CrossRef]

21. Richter, M.; Deppisch, S.; von Storch, H. Observed Changes in Long-Term Climatic Conditions and Inner-Regional Differences in Urban Regions of the Baltic Sea Coast. Atmos. Clim. Sci. 2013, 3, 165-176. [CrossRef]

22. Wienert, U.; Kreienkamp, F.; Spekat, A.; Enke, W. A simple method to estimate the urban heat island intensity in data sets used for the simulation of the thermal behaviour of buildings. Meteorol. Z. 2013, 22, 179-185. [CrossRef]

23. Grawe, D.; Thompson, H.L.; Salmond, J.A.; Cai, X.-M.; Schlünzen, K.H. Modelling the impact of urbanisation on regional climate in the Greater London Area. Int. J. Climatol. 2013, 33, 2388-2401. [CrossRef]

24. Bechtel, B.; Schmidt, K.J. Floristic mapping data as a proxy for the mean urban heat island. Clim. Res. 2011, 49, 45-58. [CrossRef]

25. Wiesner, S.; Eschenbach, A.; Ament, F. Urban air temperature anomalies and their relation to soil moisture observed in the city of Hamburg. Meteorol. Z. 2014, 23, 143-157. [CrossRef]

26. Brümmer, B.; Lange, I.; Konow, H. Atmospheric boundary layer measurements at the $280 \mathrm{~m}$ high Hamburg weather mast 1995-2011: Mean annual and diurnal cycles. Meteorol. Z. 2012, 21, 319-335. [CrossRef]

27. Bechtel, B.; Wiesner, S.; Zaksek, K. Estimation of dense time series of urban air temperatures from multitemporal geostationary satellite data. IEEE J. Sel. Top. Appl. Earth Obs. Remote Sens. 2014, 7, 4129-4137. [CrossRef]

28. Hoffmann, P.; Krueger, O.; Schlünzen, K.H. A statistical model for the urban heat island and its application to a climate change scenario. Int. J. Climatol. 2012, 32, 1238-1248. [CrossRef]

29. Trusilova, K.; Riecke, W. Klimauntersuchung für die Metropolregion Hamburg zur Entwicklung Verschiedener Meteorologischer Parameter bis zum Jahr 2050; Berichte des Deutschen Wetterdienstes Nr. 247.; DWD: Offenbach, Germany, 2015.

30. Kalnay, E.; Cai, M. Impact of urbanization and land-use change on climate. Nature 2003, 423, 528-531. [CrossRef] [PubMed] 
31. Chrysanthou, A.; van der Schrier, G.; van den Besselaar, E.J.M.; Klein Tank, A.M.G.; Brandsma, T. The effects of urbanization on the rise of the European temperature since 1960. Geophys. Res. Lett. 2014, 41, 7716-7722. [CrossRef]

32. Jones, P.D.; Lister, D.H.; Li, Q. Urbanization effects in large-scale temperature records, with an emphasis on China. J. Geophys. Res. 2008, 113. [CrossRef]

33. Li, Y.; Zhu, L.; Zhao, X.; Li, S.; Yan, Y. Urbanization Impact on Temperature Change in China with Emphasis on Land Cover Change and Human Activity. J. Clim. 2013, 26, 8765-8780. [CrossRef]

34. Parker, D.E. Urban heat island effects on estimates of observed climate change. Wiley Interdiscip. Rev. 2010, 1, 123-133. [CrossRef]

35. Wang, F.; Ge, Q.; Wang, S.; Li, Q.; Jones, P.D. A New Estimation of Urbanization's Contribution to the Warming Trend in China. J. Clim. 2015, 28, 8923-8938. [CrossRef]

36. Harris, I.; Jones, P.D.; Osborn, T.J.; Lister, D.H. Updated high-resolution grids of monthly climatic observations-The CRU TS3.10 Dataset. Int. J. Climatol. 2014, 34, 623-642. [CrossRef]

37. Schoetter, R.; Hoffmann, P.; Rechid, D.; Schlünzen, K.H. Evaluation and bias correction of regional climate model results using model evaluation measures. J. Appl. Meteorol. Climatol. 2012, 51, 1670-1684. [CrossRef]

38. Hoffmann, P.; Schoetter, R.; Schlünzen, K.H. Statistical-dynamical downscaling of the urban heat island in Hamburg, Germany. Meteorol. Z. 2016. [CrossRef]

39. Wilby, R.L. Constructing climate change scenarios of urban heat island intensity and air quality. Environ. Plan. $B$ 2008, 35, 902-919. [CrossRef]

40. Adachi, S.A.; Kimura, F.; Kusaka, H.; Inoue, T.; Ueda, H. Comparison of the Impact of Global Climate Changes and Urbanization on Summertime Future Climate in the Tokyo Metropolitan Area. J. Appl. Meteorol. Climatol. 2012, 51, 1441-1454. [CrossRef]

41. Argüeso, D.; Evans, J.P.; Fita, L.; Bormann, K.J. Temperature response to future urbanization and climate change. Clim. Dyn. 2014, 42, 2183-2199. [CrossRef]

42. Grossman-Clarke, S.; Schubert, S.; Fenner, D. Urban effects on summertime air temperature in Germany under climate change. Int. J. Climatol. 2017, 37, 905-917. [CrossRef]

43. Hamdi, R.; van de Vyver, H.; Troch, R.D.; Termonia, P. Assessment of three dynamical urban climate downscaling methods: Brussels's future urban heat island under an A1B emission scenario. Int. J. Climatol. 2014, 34, 978-999. [CrossRef]

44. Hermans, A. Impacts of Land-Cover Change on the Regional Climate of Northern Germany. Ph.D. Thesis, Universität Hamburg, Hamburg, Germany, 2016.

45. Boettcher, M.; Hoffmann, P.; Lenhart, H.-J.; Schlünzen, K.H.; Schoetter, R. Influence of large offshore wind farms on North German climate. Meteorol. Z. 2015, 24, 465-480. [CrossRef]

46. Früh, B.; Becker, P.; Deutschländer, T.; Hessel, J.-D.; Kossmann, M.; Mieskes, I.; Namyslo, J.; Roos, M.; Sievers, U.; Steigerwald, T.; et al. Estimation of climate-change impacts on the urban heat load using an urban climate model and regional climate projections. J. Appl. Meteorol. Climatol. 2011, 50, 167-184. [CrossRef]

47. Hoffmann, P.; Krueger, O.; Schlünzen, K.H. A statistical model for the urban heat island and its application to a climate change scenario. Int. J. Climatol. 2012, 32, 1238-1248. [CrossRef]

48. Hoffmann, P.; Schlünzen, K.H. Weather Pattern Classification to Represent the Urban Heat Island in Present and Future Climate. J. Appl. Meteorol. Climatol. 2013, 52, 2699-2714. [CrossRef]

49. Schlünzen, K.H.; Flagg, D.D.; Fock, B.H.; Gierisch, A.; Lüpkes, C.; Reinhardt, V.; Spensberger, C. Scientific Documentation of the Multiscale Model System M-SYS (METRAS, MITRAS, MECTM, MICTM, MESIM, MEMI); Technical Report 4; Meteorologisches Institut KlimaCampus Universitaet Hamburg: Hamburg, Germany, 2012; p. 140.

50. Boettcher, M.; Flagg, D.D.; Grawe, D.; Hoffmann, P.; Petrik, R.; Schlünzen, K.H.; Schoetter, R.; Teichert, N. Modelling impacts of urban developments and climate adaptation measures on summer climate of Hamburg. Urban Clim. 2017, submitted.

51. Arnfield, A.J. Two decades of urban climate research: A review of turbulence, exchanges of energy and water, and the urban heat island. Int. J. Climatol. 2003, 23, 1-26. [CrossRef]

52. Arnds, D.; Böhner, J.; Bechtel, B. Spatio-temporal variance and meteorological drivers of the urban heat island in a European city. Theor. Appl. Climatol. 2017, 128, 43-61. [CrossRef] 
53. Jacobson, M.Z.; Hoeve, J.E.T. Effects of urban surfaces and white roofs on global and regional climate. J. Clim. 2012, 25, 1028-1044. [CrossRef]

54. Bechtel, B.S.; Sismanidis, P. Time series analysis of moderate resolution land surface temperatures. In Remote Sensing: Time Series Image Processing; Weng, Q., Ed.; Taylor \& Francis: Abingdon, UK, 2017.

55. Bechtel, B. Robustness of annual cycle parameters to characterize the urban thermal landscapes. IEEE Geosci. Remote Sens. Lett. 2012, 9, 876-880. [CrossRef]

56. Ching, J.; Mills, G.; Bechtel, B.; See, L.; Feddema, J.; Wang, X.; Ren, C.; Brousse, O.; Martilli, A.; Neophytou, M.; et al. World Urban Database and Access Portal Tools (WUDAPT), an urban weather, climate and environmental modeling infrastructure for the Anthropocene. Bull. Am. Meteorol. Soc. 2017, in review.

57. Hein, P.; Zhu, K.; Bucher, A.; Kolditz, O.; Pang, Z.; Shao, H. Quantification of exploitable shallow geothermal energy by using Borehole Heat Exchanger coupled Ground Source Heat Pump systems. Energy Convers. Manag. 2016, 127, 80-89. [CrossRef]

58. Klein, I.; Gessner, U.; Dietz, A.J.; Kuenzer, C. Global WaterPack-A $250 \mathrm{~m}$ resolution dataset revealing the daily dynamics of global inland water bodies. Remote Sens. Environ. 2017, 198, 345-362. [CrossRef]

59. Bobrowski, M.; Bechtel, B.; Oldeland, J.; Weidinger, J.; Schickhoff, U. Upgrading ecological niche models with phenological traits: Refinement of the predicted distribution range of Betula utilis in the Himalayan region. J. Biogeogr. 2018, in review.

60. Bechtel, B. The climate of the Canary Islands by annual cycle parameters. Int. Arch. Photogramm. Remote Sens. Spat. Inf. Sci. 2016, XLI-B8, 243-250.

61. Bechtel, B.; Zaksek, K.; Hoshyaripour, G. Downscaling land surface temperature in an urban area: A case study for Hamburg, Germany. Remote Sens. 2012, 4, 3184-3200. [CrossRef]

62. Sismanidis, P.; Keramitsoglou, I.; Bechtel, B.; Kiranoudis, C.T. Improving the Downscaling of diurnal land surface temperatures using the annual cycle parameters as disaggregation kernels. Remote Sens. 2017, 9, 23. [CrossRef]

63. Sismanidis, P.; Keramitsoglou, I.; Kiranoudis, C.T.; Bechtel, B. Assessing the capability of a downscaled urban land surface temperature time series to reproduce the spatiotemporal features of the original data. Remote Sens. 2016, 8, 274. [CrossRef]

64. Zhan, W.; Huang, F.; Quan, J.L.; Zhu, X.L.; Gao, L.; Zhou, J.; Ju, W.M. Disaggregation of remotely sensed land surface temperature: A new dynamic methodology. J. Geophys. Res. 2016, 121, 10538-10554. [CrossRef]

65. Bechtel, B. Die Hitze in der Stadt verstehen-Wie sich die jahreszeitliche Temperaturdynamik von Städten aus dem All beobachten lässt. In Globale Urbanisierung_Perspektive aus dem All; Taubenböck, H., Wurm, M., Esch, T., Dech, S., Eds.; Springer Spektrum: Berlin/Heidelberg, Germany, 2015; pp. 205-216, ISBN 978-3-66244841-0.

66. Fu, P.; Weng, Q.H. A time series analysis of urbanization induced land use and land cover change and its impact on land surface temperature with Landsat imagery. Remote Sens. Environ. 2016, 175, 205-214. [CrossRef]

67. Huang, F.; Zhan, W.F.; Voogt, J.; Hu, L.Q.; Wang, Z.H.; Quan, J.L.; Ju, W.M.; Guo, Z. Temporal upscaling of surface urban heat island by incorporating an annual temperature cycle model: A tale of two cities. Remote Sens. Environ. 2016, 186, 1-12. [CrossRef]

68. Bechtel, B. Recent advances in thermal remote sensing for urban planning and management. In Proceedings of the 2015 Joint Urban Remote Sensing Event (Jurse), Lausanne, Switzerland, 30 March-1 April 2015.

69. Kaloustian, N.; Tamminga, M.; Bechtel, B. Local climate zones and annual surface thermal response in a Mediterranean city. In Proceedings of the 2017 Joint Urban Remote Sensing Event (JURSE), Dubai, UAE, 6-8 March 2017; pp. 1-4.

70. Pinto, J.G.; Reyers, M. Kapitel 8-Winde und Zyklone. In Klimawandel in Deutschland: Entwicklung, Folgen, Risiken und Perspektiven; Brasseur, G.P., Jacob, D., Schuck-Zöller, S., Eds.; Springer Spektrum: Berlin, Germany, 2016; ISBN 9783662503973.

71. Feser, F.; Barcikowska, M.; Krueger, O.; Schenk, F.; Weisse, R.; Xia, L. Storminess over the North Atlantic and northwestern Europe-A review. Q. J. R. Meteorol. Soc. 2015, 141, 350-382. [CrossRef]

72. Hov, Ø.; Cubasch, U.; Fischer, E.; Höppe, P.; Iversen, T.; Kvamstø, N.G.; Kundzewicz, Z.W.; Rezacova, D.; Rios, D.; Duarte Santos, F.; et al. Extreme Weather Events in Europe: Preparing for Climate Change Adaptation; Norwegian Meteorological Institute: Oslo, Norway, 2013; ISBN 978-82-7144-100-5. 
73. Ulbrich, U.; Leckebusch, G.C.; Pinto, J.G. Extra-tropical cyclones in the present and future climate: A review. Theor. Appl. Climatol. 2009, 96, 117-131. [CrossRef]

74. Zappa, G.; Shaffrey, L.C.; Hodges, K.I.; Sansom, P.G.; Stephenson, D.B. A Multimodel assessment of future projections of North Atlantic and European Extratropical Cyclones in the CMIP5 climate models. J. Clim. 2013, 26, 5846-5862. [CrossRef]

75. Heppelmann, T.; Steiner, A.; Vogt, S. Application of numerical weather prediction in wind power forecasting: Assessment of the diurnal cycle. Meteorol. Z. 2017, 26, 319-331. [CrossRef]

76. Hertwig, D.; Patnaik, G.; Leitl, B. LES validation of urban flow, part I: Flow statistics and frequency distributions. Environ. Fluid Mech. 2017, 17, 521-550. [CrossRef]

77. European Environment Agency. Climate Change, Impacts and Vulnerability in Europe 2016. An. Indicator-Based Report; EEA Report No 1/2017; European Environment Agency: Copenhagen, Denmark, 2017.

78. Casanueva, A.; Rodríguez-Puebla, C.; Frías, M.D.; González-Reviriego, N. Variability of extreme precipitation over Europe and its relationships with teleconnection patterns. Hydrol. Earth Syst. Sci. 2014, 18, 709-725. [CrossRef]

79. Fleig, A.K.; Tallaksen, L.M.; James, P.; Hisdal, H.; Stahl, K. Attribution of European precipitation and temperature trends to changes in synoptic circulation. Hydrol. Earth Syst. Sci. 2015, 19, 3093-3107. [CrossRef]

80. Han, J.-Y.; Baik, J.-J.; Lee, H. Urban impacts on precipitation. Asia Pac. J. Atmos. Sci. 2013, 50. [CrossRef]

81. Shepherd, J.M.; Pierce, H.; Negri, A.J. Rainfall Modification by Major Urban Areas: Observations from Spaceborne Rain Radar on the TRMM Satellite. J. Appl. Meteorol. 2002, 41, 689-701. [CrossRef]

82. Schoetter, R. Can Local Adaptation Measures Compensate for Regional Climate Change in Hamburg Metropolitan Region. Ph.D. Thesis, Universität Hamburg, Hamburg, Germany, 2013. [CrossRef]

83. Rosenhagen, G.; Schatzmann, M. Das Klima der Metropolregion auf Grundlage meteorologischer Messungen und Beobachtungen. In Klimabericht für die Metropolregion Hamburg; von Storch, H., Claussen, M., Eds.; Springer: Berlin/Heidelberg, Germany, 2011; pp. 19-60. ISBN 978-3-642-16035-6.

84. Schönwiese, C.-D.; Janoschitz, R. Klima-Trendatlas Deutschland 1901-2000. In Berichte des Instituts für Atmosphäre und Umwelt der Universität Frankfurt/Main, 2nd ed.; Eigenverlag des Instituts: Frankfurt, Germany, 2008; Volume 4.

85. Wild, M.; Folini, D.; Henschel, F.; Fischer, N.; Müller, B. Projections of long-term changes in solar radiation based on CMIP5 climate models and their influence on energy yields of photovoltaic systems. Sol. Energy 2015, 116, 12-24. [CrossRef]

86. Bartók, B.; Wild, M.; Folini, D.; Lüthi, D.; Kotlarski, S.; Schär, C.; Vautard, R.; Jerez, S.; Imecs, Z. Projected changes in surface solar radiation in CMIP5 global climate models and in EURO-CORDEX regional climate models for Europe. Clim. Dyn. 2017, 49, 2665-2683. [CrossRef]

87. Macpherson, R.K. The assessment of the thermal environment a review. Br. J. Ind. Med. 1962, 19, 151-164. [CrossRef] [PubMed]

88. De Freitas, C.R.; Grigorieva, E.A. A comprehensive catalogue and classification of human thermal climate indices. Int. J. Biometeorol. 2015, 59, 109-120. [CrossRef] [PubMed]

89. De Freitas, C.R.; Grigorieva, E.A. A comparison and appraisal of a comprehensive range of human thermal climate indices. Int. J. Biometeorol. 2017, 61, 487-512. [CrossRef] [PubMed]

90. Fischereit, J.; Schlünzen, K.H. Evaluation of thermal indices for their usability in obstacle resolving meteorology models. Int. J. Biometeorol. 2017. submitted.

91. Höppe, P. The physiological equivalent temperature-A universal index for the biometeorological assessment of the thermal environment. Int. J. Biometeorol. 1999, 43, 71-75. [CrossRef] [PubMed]

92. VDI-3787-2. Methods for the Human Biometeorological Evaluation of Climate and Air Quality for Urban and Regional Planning at Regional Level, Part I: Climate; Beuth: Berlin, Germany, 2008.

93. Matzarakis, A.; Amelung, B. Physiological equivalent temperature as indicator for impacts of climate change on thermal comfort of humans. In Seasonal Forecasts, Climatic Change and Human Health: Health and Climate; Thomson, M.C., Garcia-Herrera, R., Beniston, M., Eds.; Springer: Dordrecht, The Netherlands, 2008; pp. 161-172, ISBN 978-1-4020-6877-5.

94. Jendritzky, G.; Tinz, B. The thermal environment of the human being on the global scale. Glob. Health Action 2009, 2, 2005. [CrossRef] [PubMed] 
95. Staiger, H. Die Strahlungskomponente im Thermischen Wirkungskomplex für Operationelle Anwendungen in der Human-Biometeorologie. Ph.D. Thesis, Geowissenschaften, Albert-Ludwigs-Universität Freiburg im Breisgau, Freiburg im Breisgau, Germany, 2014.

96. Rigollier, C.; Bauer, O.; Wald, L. On the clear sky model of the ESRA—European Solar Radiation Atlas-With respect to the Heliosat method. Sol. Energy 2000, 68, 33-48. [CrossRef]

97. Scharmer, K.; Greif, J. The European Solar Radiation Atlas: Fundamentals and Maps; Les Presses de l'Ecole des Mines: Paris, France, 2000; ISBN 9782911762215.

98. Remund, R.; Wald, L.; Lefevre, M.; Ranchin, T.; Page, J. Worldwide Linke Turbidity Information. In Proceedings of the ISES Solar World Congress, Gothenburg, Sweden, 16-19 June 2003; p. 13.

99. Kasten, F. Parametrisierung der Globalstrahlung durch Bedeckungsgrad und Truebungsfaktor. In Proceedings of the Deutsche Meteorologen-Tagung 1983 vom 16. bis 19. Mai 1983, Bad Kissingen, Germany, 16-19 May 1983; pp. 49-50.

100. Reindl, D.T.; Beckman, W.A.; Duffie, J.A. Diffuse fraction correlations. Sol. Energy 1990, 45, 1-7. [CrossRef]

101. Konzelmann, T.; van de Wal, R.S.W.; Greuell, W.; Bintanja, R.; Henneken, E.A.C.; Abe-Ouchi, A. Parameterization of global and longwave incoming radiation for the Greenland Ice Sheet. Glob. Planet. Chang. 1994, 9, 143-164. [CrossRef]

102. Marty, C.; Philipona, R. The Clear-Sky Index to separate clear-sky from cloudy-sky situations in climate research. Geophys. Res. Lett. 2000, 27, 2649-2652. [CrossRef]

103. Jendritzky, G. Methodik zur Räumlichen Bewertung der Thermischen Komponente im Bioklima des Menschen: Fortgeschriebenes Klima-Michel-Modell; Akademie für Raumforschung und Landesplanung: Hannover, Germany, 1990; ISBN 9783888382079.

104. Fischereit, J. Impact on Urban Water Surfaces on Thermal Microclimate. Ph.D. Thesis, Universität Hamburg, Hamburg, Germany, 2018.

105. Thorsson, S.; Lindberg, F.; Björklund, J.; Holmer, B.; Rayner, D. Potential changes in outdoor thermal comfort conditions in Gothenburg, Sweden due to climate change: The influence of urban geometry. Int. J. Climatol. 2011, 31, 324-335. [CrossRef]

106. Molenaar, R.E.; Heusinkveld, B.G.; Steeneveld, G.J. Projection of rural and urban human thermal comfort in The Netherlands for 2050. Int. J. Climatol. 2016, 36, 1708-1723. [CrossRef]

107. Maxwell, R.M.; Kollet, S.J. Interdependence of groundwater dynamics and land-energy feedbacks under climate change. Nat. Geosci. 2008, 1, 665-669. [CrossRef]

108. Taylor, R.G.; Scanlon, B.; Doll, P.; Rodell, M.; van Beek, R.; Wada, Y.; Longuevergne, L.; Leblanc, M.; Famiglietti, J.S.; Edmunds, M.; et al. Ground water and climate change. Nat. Clim. Chang. 2013, 3, 322-329. [CrossRef]

109. Pfeiffer, E.-M.; Eschenbach, A.; Munch, J.C. Kapitel 20-Boden. In Klimawandel in Deutschland: Entwicklung, Folgen, Risiken und Perspektiven; Brasseur, G., Jacob, D., Schuck-Zöller, S., Eds.; Springer Spektrum: Berlin, Germany, 2016; ISBN 978-3-662-50397-3.

110. Wiesner, S.; Gröngröft, A.; Ament, F.; Eschenbach, A. Spatial and temporal variability of urban soil water dynamics observed by a soil monitoring network. J. Soils Sediments 2016, 16, 2523-2537. [CrossRef]

111. Lee, S.-H.; Lee, K.-S.; Jin, W.-C.; Song, H.-K. Effect of an urban park on air temperature differences in a central business district area. Landsc. Ecol. Eng. 2009, 5, 183-191. [CrossRef]

112. Jansson, C.; Jansson, P.-E.; Gustafsson, D. Near surface climate in an urban vegetated park and its surroundings. Theor. Appl. Climatol. 2007, 89, 185-193. [CrossRef]

113. Wessolek, G. Bodenüberformung und -versiegelung. In Handbuch der Bodenkunde; Wiley-VCH Verlag GmbH \& Co. KGaA: Weinheim, Germany, 2014; ISBN 9783527678495.

114. Jung, M.; Reichstein, M.; Ciais, P.; Seneviratne, S.I.; Sheffield, J.; Goulden, M.L.; Bonan, G.; Cescatti, A.; Chen, J.Q.; de Jeu, R.; et al. Recent decline in the global land evapotranspiration trend due to limited moisture supply. Nature 2010, 467, 951-954. [CrossRef] [PubMed]

115. Lee, A.C.K.; Maheswaran, R. The health benefits of urban green spaces: A review of the evidence. J. Public Health 2011, 33, 212-222. [CrossRef] [PubMed]

116. Peters, E.B.; Hiller, R.V.; McFadden, J.P. Seasonal contributions of vegetation types to suburban evapotranspiration. J. Geophys. Res. 2011, 116, 16. [CrossRef] 
117. Coutts, A.M.; Tapper, N.J.; Beringer, J.; Loughnan, M.; Demuzere, M. Watering our cities: The capacity for Water Sensitive Urban Design to support urban cooling and improve human thermal comfort in the Australian context. Prog. Phys. Geogr. 2013, 37, 2-28. [CrossRef]

118. Günther, R. The role of soil water content for microclimatic effects of green roofs and urban trees-A case study from Berlin, Germany. J. Heat Isl. Inst. Int. 2014, 9, 19-25.

119. Jelinkova, V.; Dohnal, M.; Sacha, J. Thermal and water regime studied in a thin soil layer of green roof systems at early stage of pedogenesis. J. Soils Sediments 2016, 16, 2568-2579. [CrossRef]

120. Nielsen, C.N.; Bühler, O.; Kristoffersen, P. Soil water dynamics and growth of street and park trees. Arboric. Urban For. 2007, 33, 231-245.

121. Cregg, B.M.; Dix, M.E. Tree moisture stress and insect damage in urban areas in relation to heat island effects. J. Arboric. 2001, 27, 8-17.

122. Clark, J.K.; Kjelgren, R. Water as a limiting factor in the development of urban trees. J. Arboric. 1990, 16, 203-208.

123. Rahman, M.A.; Armson, D.; Ennos, A.R. A comparison of the growth and cooling effectiveness of five commonly planted urban tree species. Urban Ecosyst. 2015, 18, 371-389. [CrossRef]

124. Rahman, M.A.; Moser, A.; Rötzer, T.; Pauleit, S. Microclimatic differences and their influence on transpirational cooling of Tilia cordata in two contrasting street canyons in Munich, Germany. Agric. For. Meteorol. 2017, 232, 443-456. [CrossRef]

125. Thomsen, S. Impact of Soil Water Availability and Local Climate in Urban Environments on Water Use of Mature Pedunculate oaks (Quercus Robur L.). Ph.D. Thesis, Universität Hamburg, Hamburg, Germany, 2018.

(C) 2018 by the authors. Licensee MDPI, Basel, Switzerland. This article is an open access article distributed under the terms and conditions of the Creative Commons Attribution (CC BY) license (http:/ / creativecommons.org/licenses/by/4.0/). 